\title{
Children's Right to Grow up in a Family
}

\author{
Ivana Visković \\ Faculty of Education, University of Hercegovina, Bijakovići, Bosnia and Herzegovina \\ viskovicivana@hercegovuina.edu.ba,viskovicivana@gmail.com
}

\begin{abstract}
Growing up in a family is one of the fundamental rights of children, which places the obligation on a family to provide optimal conditions for the growth and development of any individual. Children's right to grow up in a family is regulated by law and state policy measures which try to improve the functioning of the family. The functioning of the family can be interpreted through the ways in which a family fulfils its functions. It is determined by family structure as the construct of relationships between family members and behavioural patterns they develop in time, and it is significant in order to ensure the requirements for growing up, providing a behavioural model and development of an individual's personality. Unfavourable economic status, especially of single-parent families, indirectly reflects on children in many ways. This paper provides an overview of one part of the results obtained from researching the opinions of experts and practitioners on the quality of family functioning in the Republic of Croatia. State policy measures can make family functioning easier, the participants in this research estimate that the quality of growing up in a family primarily depends on mutual attachment and emotional connection of its members.
\end{abstract}

Keywords: (dis)functional families, growing up in a family, educational outcomes, children's rights

\section{INTRODUCTION}

A family is often the first, and possibly the most important, community of growing of individuals. In accordance with legal guidelines and cultural norms, personal emotional choices of an individual, as well as with both general and specific economic and social conditions, a family provides conditions for growth and development of the individual, together with the implementation and protection of their rights. Growing up in a family, primarily determined by socio-emotional ties between family members and the ways in which families fulfil their functions, strongly shapes the personality of each individual, even when that impact is apparently absent (for example, the impact of the absent parent). Families are still a (non-)conscious network of human relationships [1] and the source of many, especially emotional, expectations. Minuchin [2] states that each member of the family always, openly or latently, responds to the processes and changes, events and possible pressures on and in the family, and that this process is a two-way street - individuals' reactions likewise affect the family. The right of a child to grow up in a family assumes living in a quality social, emotional and physicalmaterial environment, meeting the psycho-physical, socio-emotional, existential, developmental and protection needs, as well as the right to actively participate in personal development. The Preamble to the Convention on the Rights of the Child states that the child, in order to fully and harmoniously develop his or her personality, should grow up in a family environment, in an atmosphere of happiness, love and understanding. Such conditions of growing up can primarily be ensured by healthy, stable and functional families that provide security and build a safe attachment between its members. Social changes and developments affect the family structurally and functionally: new family structures can be noted, the roles of family members are being redefined, together with mutual rights and obligations, while certain family functions are being taken over by the society. It is possible to assume that structural, functional and operational changes of the institution of family reflect on the realization of children's right to grow up functional families.

\section{LEGISLATION ON THE RIGHTS OF CHILDREN TO GROW UP IN A FAMILY}

By ratification of international conventions, the Republic of Croatia has committed to provide optimal conditions for the realization of children's rights. The Family Policy and measures of social protection 
strive to contribute to the quality of family life and the welfare of children in a family. The motherhood, children and youth are thus being protected, and the legal guidelines oblige both parents to take care of their children, provide them with optimal conditions for growth, development and education. At the same time, the State guarantees that it will not interfere unduly with the private life of an individual. The right to grow up in a family is secured even for children who have lost their primary family (through death or abandonment of a parent, or exclusion from family). The results of certain studies [3] indicate that children exempted from the care of their biological parents were usually exposed to family abuse and neglect, as well as economically vulnerable or socially deprived, which increases their risk of poverty, lack of education and poorer health outcomes. It is the obligation of the state to also provide such children with the right to grow up in a family, i.e. to find alternative families (foster or adoptive families) that will provide them with continuous, stable interactive emotional relationships, as well as with cultural continuity [4].

\section{FAMILY FUNCTIONING}

Family functioning is a hypothetical construct of the ways in which family members mutually interact and meet specific functions of a family, develop emotional relationships and behaviour, resolve problems and share the power. Communication forms and quality represent an operative level of family function and may function as a model and a tool of transmission. Family functioning can be identified as functional (healthy) and dysfunctional [5]. Healthy, functional families are identified as families with the aim of achieving their own family goals and of systematic construction and development of family relationships [6]. Relationships in these families are characterized by commitment, love, loyalty, interdependence, solidarity and caring. Communication is two-way and constructive, emotional expressiveness clear, while problematic situations are solved through agreement with a willingness to change, therefore it is possible to assume efficiency. In such families, children are accepted as active parts of family functioning and are encourage to achieve independence appropriate for their age [7]. Marital and parental roles of partners are differentiated, while commonlaw spouses are able to maintain clear boundaries of their individuality. The family system is balanced through semipermeable borders. Wagner Jakab [8] interprets a functional family as a stimulating family which, through optimal organization and balance of time and activities (learning, working, leisure time, family obligations and rituals), together with connection to the community (extended family, educational institutions, environment), provides the child with a complete physical and mental development in accordance with individual abilities of the child and building of basic values such as trust, solidarity, cooperation, education, respect for individuality and differences. Dysfunctional families are recognizable primarily by emotional remoteness and a lack of good communication, which characterizes them with a high risk for the optimal development of children [9]. As determinants of the quality of family functioning it is possible to identify [10]:

- Internal cohesion of family members (family cohesiveness) through which family members meet their needs for love, belonging, intimacy and attachment;

- Flexibility as the ability of a family to adapt to development cycles, family processes and possible stressful situations, crises and traumas, as well as to everyday situations;

- Clearly defined boundaries of the family as a system, and permeability of borders in relation to the social environment;

- Means of distribution of power discernible through roles, decision-making and problem-solving situations;

- Communication as an operational modality of family cohesion, flexibility and parental style, recognizable in emotional expressions.

By combining a range of specific dimensions of family functioning [Figure 1] sixteen possible types of families can be identified, wherein extreme positions assume dysfunctional tendencies [11]. Communication was not presented as a factor in the graphic model since it only represents an operational level of family functioning dimensions. 


\begin{tabular}{|c|l|l|l|l|}
\multicolumn{5}{c}{ Integration } \\
\cline { 2 - 5 } & $\begin{array}{l}\text { Chaotically } \\
\text { excluded }\end{array}$ & $\begin{array}{l}\text { Chaotically } \\
\text { separated }\end{array}$ & $\begin{array}{l}\text { Chaotically } \\
\text { integrated }\end{array}$ & $\begin{array}{l}\text { Chaotically } \\
\text { intertwined }\end{array}$ \\
\cline { 2 - 5 } & $\begin{array}{l}\text { Flexibly } \\
\text { Flexibly } \\
\text { excluded }\end{array}$ & $\begin{array}{l}\text { partially) } \\
\text { separated }\end{array}$ & $\begin{array}{l}\text { Flexibly } \\
\text { integrated }\end{array}$ & $\begin{array}{l}\text { Flexibly } \\
\text { intertwined }\end{array}$ \\
\cline { 2 - 5 } & $\begin{array}{l}\text { Structurally } \\
\text { (partially) } \\
\text { separated }\end{array}$ & $\begin{array}{l}\text { Structurally } \\
\text { integrated }\end{array}$ & $\begin{array}{l}\text { Structurally } \\
\text { intertwined }\end{array}$ \\
\cline { 2 - 6 } & $\begin{array}{l}\text { Strictly } \\
\text { excluded }\end{array}$ & $\begin{array}{l}\text { Strictly } \\
\text { separated }\end{array}$ & $\begin{array}{l}\text { Strictly } \\
\text { integrated }\end{array}$ & $\begin{array}{l}\text { Strictly } \\
\text { intertwined }\end{array}$ \\
\hline
\end{tabular}

Figure1. Integration model of Family Functioning

The balance of dimensions, together with quality communication, has the tendency of quality functioning (white areas). Families with an unbalanced style find it harder to cope with stress and pressures that cause changes (dark grey areas) and have poor communication skills. Families of mixed structure (grey areas) find it difficult to cope with pressure, but because of the (partial) integration have the ability of achieving quality changes. Under the influence of environment factors, mixed family systems (central level dimensions of family functioning) have a tendency of adjusting (changes in structure, roles, managing) as opposed to unbalanced, extreme systems that remain "stuck" in their own form of non-functioning. In quality family functioning, associated extreme ranges are possible, such as extremely high emotional connection with strong individuality in the professional field. Specific conditions through which families meet their basic needs, self-fulfilment of members and social interaction are the reason to, while assessing the quality of family functioning, examine the broader context of the social environment. Over time, family functioning can change in respect to all of its dimensions depending on the environment, but also on the life cycle, personalities and wishes of each individual family member. When the aspirations of a specific family member change (for example, focus on the professional career), that is most often reflected in family functioning and, directly or indirectly, the welfare of children in the family. The family, like most other communities, generally represents a nonlinear dynamic system, exposed to crises and conflict situations in which they operate, with over, and a set of latent variables, both internal and external, which contribute to the complexity of family functioning. Therefore, every family has the potential to be (dis)functional. However, functional families are not without stress, conflict and problem situations; they timely, flexibly and effectively respond to the needs of their members, taking into account their right to privacy.

\section{FAMILY FUnCTIONS}

As permanent family functions, one can be identify the biologically-reproductive, educational, economic, and possibly the most important, socio-emotional function of the family. Most other family function change within the development of society (e.g., common housing), while certain functions (e.g., education, safety, care for the elderly) are taken over by the society. At the same time, relatively new, but not less important, functions of the family appear (such as joint leisure time).

\section{FAMILY STRUCTURE}

Structurally, a family assumes a community of parents and their biological children or adopted, together with complex interactive relationships among them, recognizable by their emotional connection, attachment and expressiveness. The structure of the family is not adequately interpreted only through factors (parents - offspring), but through relationships of its members, i.e. the repetitive patterns of interaction which family members develop over time. Although there are doubts and controversies in regard to parentage determination (biological - social - replacement; heterogeneous homosexual couples; absent parents), children are a fundamental family factor, therefore it is reasonable to take into view that the community of partners becomes a family only after the arrival of children. Modern society families are undergoing a structural change and there is a noticeable growing tendency of non-traditional family structures [12], recognizable as single-parent families, 
"patchwork" families, families with absent members, "calendar families", substitute (foster, adoptive) families and families with same-sex partners. Families are increasingly smaller - core and twogeneration families. Additionally, the number of children in families is also decreasing because of the rising cost of raising children [13]. Simultaneously, as a result of the long lasting economic crisis, young people are economically dependent on their families and are continuing to live with them for longer periods of time than before. Modern families live relatively alone, which usually leads to a lack of support from the family social network and may adversely affect the welfare of children. Employment of mothers is one of the factors of change in traditional patterns of family structure. Higher education of working mothers bears a positive correlation with the smaller number of children in the family, but is negatively correlated with the time of maternal care [14]. At the same time, fathers are becoming increasingly involved in child care. Family relationships are (predominantly) egalitarian, and parents jointly care for children, which may contribute to the welfare of children in the family [15]. Although it is possible to regard a complete family of stable structure featuring heterosexual biological parents as an optimal growing environment [16], an unambiguous correlation of family structure and children welfare has not been proved as such. It is possible to assume that incomplete families include worse economic conditions, and that a parent is more likely to feel overwhelmed and frustrated, which can negatively affect the quality of parenting, relationship with children, children's development and achievements [17].

Doubts also arise in assessing the impact of growing up of children in families of same-sex couples. In such families, children learn about tolerance, understanding and acceptance of diversity, but the social acceptance of such children is different [18]. Data on homosexual marriages in Scandinavia suggest that a relationship between partners of the same sex is less durable, and bears a higher risk of divorce [19]. Interactive connection in family structure, conditions of growing up and outcomes for children Wise [20] presents with the help of the influence model [Figure 2].

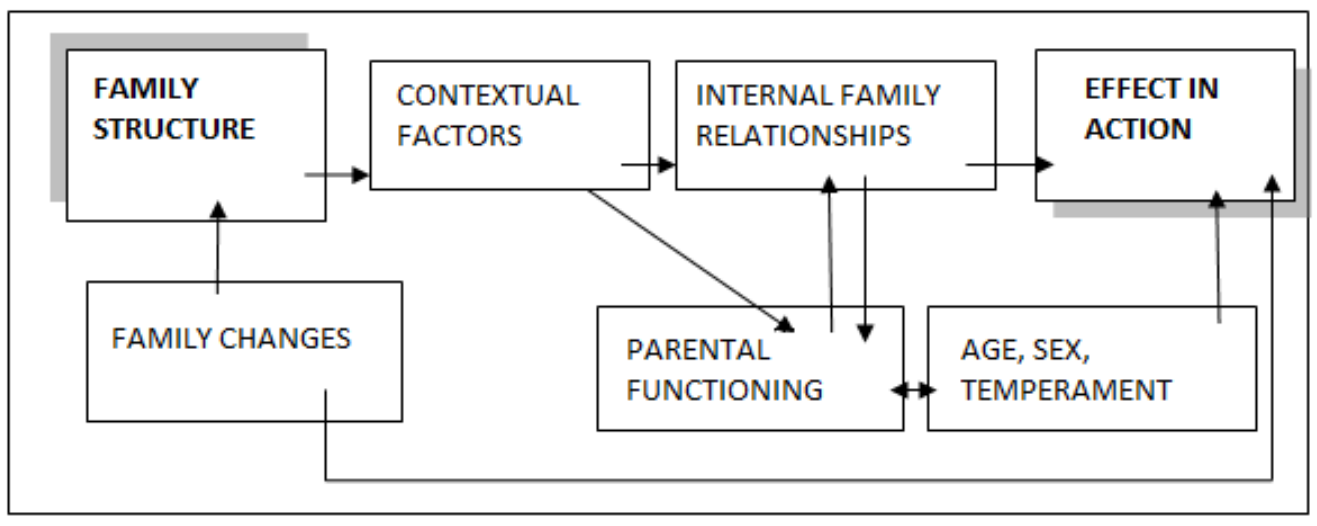

Figure2. Connection between family structure and influence on growing up of children

This model indicates the importance of mediators (social support, professional satisfaction of parents, and quality of family functioning) on the outcomes which the family structure has on growing up of children. Certain contextual factors, apparently independent in relation to family structure (e.g. financial pressure) can affect the family function on the whole, as well as the conditions of growing up of children (for example, it is possible to expect an adverse financial status of single-parent families). The number of children in a family, the order of birth and the children's mutual relationships are likewise structurally significant. Sibling relationships (between the children) can be significant for child development in terms of mutual support, empathy and caring attitudes. As opposed to positive effects (safe attachment, security, cooperation), negative relationships among children are characterized by hostility and which present a less researched, but significant, area nevertheless. Through the analysis of family structure and educational outcomes of an individual, it is possible to conclude that there is no unanimous linear correlation between family structure and individuals' outcomes. Certain authors believe that children can achieve a quality development in any type of family structure as long as emotional, social and economic stabilities are present [21] and that the balance of internal and external factors, including the influence of public policies that affect the behaviour of parents and enable parental participation in the growing up of children. Such attitude increases the responsibility of parents and the society in assuring the conditions of children's growing up in a family, long-term recognizable also through the transfer of parenthood [22]. 


\section{METHOdOLOGICAL FrameWORK OF THE RESEARCH ON EXPERTS' OPINION}

With the help of the Delphi method (a procedure consisting of anonymous group discussions without the social pressure), the opinion of experts - scientists and practitioners in the Republic of Croatia was researched on the quality and prospects of family functioning development in the Republic of Croatia. This paper reviews a small part of the research results relating to changes in the family that affect the realization of children's right to grow up in families, state policy measures which can contribute to the quality of the conditions of children's growing up in a family and the need for learning about the rights. The aim of the research was not necessarily to reach a consensus nor a statistically significant result; it was to gather reasoned opinions that can contribute to the understanding of the subject of the research [23] and offer guidance for further research and action featuring the optimal interest of children. During the selection of the survey sample, a view was taken into account that heterogeneous groups generate a more accurate judgment than the experts in homogeneous groups [24]. Accordingly, experts, scholars and practitioners of different areas were called to participate: pedagogy, psychology, education-rehabilitation, sociology, medicine, economics, theology and family law. The sample was intentional, stratified and included 15 scientists and 19 practitioners [Table 1].

Table1. Research Participants Acc ording to Scientific Areas.

\begin{tabular}{|l|l|l|l|l|}
\hline \multicolumn{2}{|c|}{} & Scientists & Practitioners & Total \\
\hline \multirow{5}{*}{} & Pedagogy & 8 & 8 & 16 \\
\cline { 2 - 5 } & Psychology & 3 & 5 & 8 \\
\cline { 2 - 5 } & Education-rehabilitation & 0 & 1 & 1 \\
\cline { 2 - 5 } \begin{tabular}{c} 
Scientific \\
\cline { 2 - 5 }
\end{tabular} & Sociology & 1 & 0 & 2 \\
\cline { 2 - 5 } & Psychiatry & 1 & 0 & 1 \\
\cline { 2 - 5 } & Theology & 1 & 1 & 2 \\
\cline { 2 - 5 } & Economy & 1 & 0 & 2 \\
\cline { 2 - 5 } & Law & 0 & 2 & 2 \\
\cline { 2 - 5 } & Politics & 15 & 2 & 34 \\
\hline
\end{tabular}

The instrument of the first round was constructed on the basis of theoretical analysis of recent literature without mentioning the source. Participants were invited to assess the compliance with the given statements, to generate new ideas and argue them. The classic Delphi method was carried out through three rounds. Assessment of the statements was possible on a six-level dichotomous coded scale, without the zero point in order to stimulate discussion. The gathered data were analysed through measures of descriptive statistics (measures of central tendency, measures of variability), while the response distribution was determined using the Kolmogorov-Smirnov test. An absolute consensus of participants' responses was considered when the $95 \%$ of estimates of the same direction was achieved, while the relative consensus was taken as the $75 \%$ of the statements of the same direction. The generated and argumentative statements were returned to the assessment of all research participants. Reliability of the instrument was determined by Cronbach's Alpha coefficient and it was .939 (ranging from .933 to .941) which is extremely high compared to the (relatively) small sample. The validity was provided by triangulation with the results of recent research in the Republic of Croatia and abroad.

\section{RESUlTS AND DISCUSSION}

By analysing the determinants of families, participants in the study assume that the family will still undergo structural alterations [Table 2] and that it is justified to assume the growth of non-traditional family structures, which is in agreement with the available statistic data (CBS RC, Eurostat).

Table2. Assumed Changes in Family Structure in the Republic of Croatia (Absolute Consensus of Participants).

\begin{tabular}{|l|l|l|l|}
\hline & $\mathrm{M}$ & $\mathrm{SD}$ & $\mathrm{v}$ \\
\hline The number of complete families will decrease. & 4.64 & 1.113 & 1.239 \\
\hline The number of single-parent families will increase. & 4.64 & 1.025 & 1.051 \\
\hline The number of common-law marriages will increase. & 4.61 & 1.223 & 1.496 \\
\hline The number of patchwork families will increase. & 4.48 & 1.253 & 1.570 \\
\hline Volatility in marital relationships will lead to a significant increase in divorce rate. & 4.48 & 1.034 & 1.070 \\
\hline The number of children in families will decrease & 4.27 & .911 & .830 \\
\hline
\end{tabular}


The certainty of change in family structures reasonably directs research on the understanding of the family, while the systematic and professional action requires identifying important areas and indicators of evaluation. By analysing the preconditions of the quality of family functioning [Table 3], participants in the study consider, as the most important indicators: the relationship between family members, their mutual affection and communication, as well as the operational level of relationships. This assessment concurs with the recent research which consider emotional connection and cooperation of family members as the most important factors of family functioning. Agreement was not achieved in regard to the assessment of the impact of the economic and social status of the family, nor the impact of parental education, on the quality of family functioning.

Table3. Indicators of Family Functioning Quality.

\begin{tabular}{|l|l|l|l|}
\hline & $\mathrm{M}$ & $\mathrm{SD}$ & $\mathrm{V}$ \\
\hline Mutual attachment & 5.58 & .708 & .502 \\
\hline Emotional connection between family members & 5.44 & 1.045 & 1.093 \\
\hline Two-way, open communication & 5.42 & .792 & .627 \\
\hline Mutual trust between family members & 5.39 & .827 & .684 \\
\hline Expressed attachment between spouses & 5.24 & .902 & .814 \\
\hline Time spent together & 5.12 & .992 & .985 \\
\hline Cooperative, democratic relationships & 5.06 & .966 & .934 \\
\hline Self-fulfilment of family member & 4.97 & .883 & .780 \\
\hline Parental harmony & 4.97 & 1.104 & 1.218 \\
\hline Flexible structure of family time & 4.91 & .980 & .960 \\
\hline Flexibility of family roles & 4.72 & 1.054 & 1.112 \\
\hline Optimism of family members & 4.66 & 1.096 & 1.201 \\
\hline Existence of and adherence to norms & 4.52 & 1.176 & 1.383 \\
\hline Autonomy of family members & 4.33 & .924 & .854 \\
\hline Economic status of the family* & 3.84 & 1.273 & 1.620 \\
\hline Social status of the family $*$ & 3.88 & 1.139 & 1.297 \\
\hline Parents' education * & 3.82 & 1.044 & 1.091 \\
\hline
\end{tabular}

* Elements with contrasting assessments

Within the factor analysis, the method of the main components was applied [Table 4]. High variance saturation is visible with all the elements of assessment (ranging from, 732 to, 922). Through application of the Scree Test, two factors were singled out, emotional connection and economic independence of the family, which together account for $62.17 \%$ of the variance.

Table4. Components and Communalities Scale Indicators of family functioning quality.

\begin{tabular}{|l|l|l|l|}
\hline & Factor saturation & Communalities & \% of variance \\
\hline Emotional connection between family members & .842 & .460 & 50.489 \\
\hline Economic independency & .758 & .626 & 11.728 \\
\hline Mutual trust & .836 & .747 & 6.626 \\
\hline Mutual attachment & .572 & .533 & 5.724 \\
\hline Two-way, open communication & .816 & .624 & 5.578 \\
\hline Self-fulfilment & .850 & .787 & 3.993 \\
\hline Cooperative, democratic relationships & .763 & .657 & 3.457 \\
\hline Expressed attachment of spouses & .878 & .769 & 2.713 \\
\hline Flexible structure of family time & .905 & .761 & 2.436 \\
\hline Time spent together & .757 & .799 & 1.442 \\
\hline Parental harmony & .791 & .780 & 1.293 \\
\hline Flexibility of family roles & .922 & .878 & 1.213 \\
\hline Adaptability of family structure & .889 & .852 & .936 \\
\hline Existence of and adherence to norms & .807 & .799 & .826 \\
\hline Optimism & .742 & .819 & .382 \\
\hline Autonomy of family members & .774 & .813 & .250 \\
\hline Social status & .732 & .613 & .186 \\
\hline Parents' education & .786 & .433 & .101 \\
\hline
\end{tabular}

The factor analysis explored the possible correlation between the elements of assessment. Participants assessed [Table 5] the following: 
- Emotional connection between family members is dependent on mutual trust,

- Mutual trust between the members is associated with self-fulfilment of members and flexibility of family structures,

- Optimism as an indicator of the quality of family functioning is related to the social status of the family,

- Economic status of the family is connected to the social status and autonomy of family members,

- Expressed attachment between spouses is connected to parental harmony, the existence of and adherence to norms and to flexibility of family roles.

Table5. Link between Certain Aspects of Family Functioning.

\begin{tabular}{|c|c|c|c|c|c|c|c|c|c|c|c|c|c|c|c|c|c|c|}
\hline & & $\mathrm{V} 2$ & V3 & $\mathrm{V} 4$ & V5 & V6 & V7 & V8 & V9 & V10 & V11 & V12 & V13 & V14 & V15 & V16 & V17 & V18 \\
\hline V1 & $\begin{array}{l}\text { Emotional connection } \\
\text { between family } \\
\text { members }\end{array}$ & .252 & .657 & .381 & .703 & .193 & .404 & .466 & .151 & .531 & .418 & .234 & .171 & .222 & .364 & .190 & -.090 & -.012 \\
\hline $\mathrm{V} 2$ & $\begin{array}{l}\text { Economic } \\
\text { independency }\end{array}$ & 1 & .453 & .332 & .424 & .619 & .573 & .508 & .296 & .428 & .414 & .396 & .496 & .274 & .393 & .488 & .395 & .269 \\
\hline $\mathrm{V3}$ & Mutual trust & & 1 & .588 & .662 & .502 & .545 & .776 & .415 & .679 & .617 & .496 & .578 & .296 & .507 & .410 & .278 & .080 \\
\hline \begin{tabular}{|l|}
$\mathrm{V} 4$ \\
\end{tabular} & Mutual attachment & & & 1 & .419 & .412 & .258 & .441 & .294 & .612 & .379 & .326 & .367 & .053 & .345 & .362 & .173 & -.027 \\
\hline V5 & $\begin{array}{l}\text { Two-way, open } \\
\text { communication }\end{array}$ & & & & 1 & .393 & .492 & .394 & .446 & .540 & .401 & .473 & .242 & .218 & .465 & .398 & .131 & .175 \\
\hline V6 & Self-fulfilment & & & & & 1 & .589 & .573 & .681 & .439 & .573 & .625 & .652 & .169 & .618 & .691 & .588 & .308 \\
\hline V7 & $\begin{array}{l}\text { Cooperative, } \\
\text { democratic } \\
\text { relationships }\end{array}$ & & & & & & 1 & .440 & .484 & .468 & 334 & 600 & .465 & .144 & .439 & .528 & .241 & .298 \\
\hline V8 & $\begin{array}{l}\text { Expressed attachment } \\
\text { of spouses }\end{array}$ & & & & & & & 1 & .326 & .731 & .731 & .489 & .700 & .426 & .568 & .506 & .409 & .323 \\
\hline V9 & $\begin{array}{l}\text { Flexible family } \\
\text { structure }\end{array}$ & & & & & & & & 1 & .458 & .531 & .802 & .642 & .281 & .683 & .761 & .512 & .199 \\
\hline V10 & Time spent together & & & & & & & & & 1 & .631 & .664 & .538 & .408 & .624 & .576 & .309 & .318 \\
\hline V11 & Parental harmony & & & & & & & & & & 1 & .527 & .690 & .379 & .756 & .619 & .459 & .131 \\
\hline V12 & $\begin{array}{l}\text { Flexibility of family } \\
\text { roles }\end{array}$ & & & & & & & & & & & $.907 \mid$ & .634 & .439 & .778 & .760 & .620 & .453 \\
\hline V13 & $\begin{array}{l}\text { Economic status of the } \\
\text { family }\end{array}$ & & & & & & & & & & & 1 & .686 & .595 & .704 & .711 & .510 & .465 \\
\hline V14 & $\begin{array}{l}\text { Existence of and } \\
\text { adherence to norms }\end{array}$ & & & & & & & & & & & & 1 & .589 & .561 & .617 & .579 & .291 \\
\hline V15 & Optimism & & & & & & & & & & & & & & 1 & .722 & .485 & .339 \\
\hline V16 & $\begin{array}{l}\text { Autonomy of family } \\
\text { members }\end{array}$ & & & & & & & & & & & & & & & 1 & .565 & .406 \\
\hline V17 & $\begin{array}{l}\text { Social status of the } \\
\text { family }\end{array}$ & & & & & & & & & & & & & & & & 1 & .589 \\
\hline V18 & Parents' education & & & & & & & & & & & & & & & & & 1 \\
\hline
\end{tabular}

Contrasting assessments within the evaluation of the contribution of certain elements to the quality of family functioning were given by participants in relation to socio-economic status of the family and parents' education. Through an anonymous discussion, participants argued their attitudes and ultimately achieved consensus on the assessment regarding the view that the economic status of the family, through levels of parental stress, indirectly affects the quality of family functioning [Table 6].

Table6. Assessment of Consequences of Economic Status of the Family

\begin{tabular}{|l|l|l|l|}
\hline & M & SD & V \\
\hline $\begin{array}{l}\text { Parental stress will increase (as a consequence of economic crisis and the } \\
\text { absence of social support to parenting) which will reflect negatively on the } \\
\text { stability of the family. * }\end{array}$ & 4.76 & .93 & .87 \\
\hline $\begin{array}{l}\text { The economic crisis (unemployment and insolvency) will reflect negatively on } \\
\text { the conditions of growing up in a family * }\end{array}$ & 4.45 & 1.22 & 1.50 \\
\hline $\begin{array}{l}\text { The economic crisis will account for increasing health problems of individuals } \\
\text { which will additionally hinder family functioning.* }\end{array}$ & 4.09 & 1.40 & 1.96 \\
\hline $\begin{array}{l}\text { The social status of parents will determine the children's social achievements } \\
\text { (academic career, employment). ** }\end{array}$ & 3.67 & 1.29 & 1.66 \\
\hline $\begin{array}{l}\text { The economic crisis will determine an increasing cohesiveness of the extended } \\
\text { family. *** }\end{array}$ & 2.88 & .89 & .79 \\
\hline
\end{tabular}

* absolute consensus $\quad * *$ relative consensus $\quad * * *$ contrary assessments retained 
Participants retained their opposing attitudes in assessing the outcome of the economic crisis on the cohesiveness of the extended family. While a number of the participants believe that Croatia is dominated by the traditional patterns of connection between the extended family which can provide support for families during crisis, others estimate that the changes in family structure have already ruptured these bonds.

Although research participants agree that the quality of family functioning represents a significant predictor of the realization of children's rights to grow up in a family, doubts have been observed in relation to the need for teaching children about their rights. Participants link the children's rights with their obligations [Table 7] and state that the rights should be taught simultaneously with the obligations. The statement of one participant of the discussion was given to the group in order to discuss it.

Table7. Research Participants' Assessment.

\begin{tabular}{|l|l|l|l|}
\hline & M & SD & v \\
\hline Children should learn both about their rights and their obligations & 4.59 & .94 & .89 \\
\hline
\end{tabular}

For the statement Children should learn both about their rights and their obligations, high consensus was achieved among research participants (91.17\%) of statements share the same direction). Individuals, educators-practitioners $(\mathrm{N}=2)$ expressed their disagreement, stating that obligations do not represent predictors of law, and all individuals acquire (and retain) the rights through birth. Those rights are retained even when individuals fail to meet their obligations, or neglect the rights of others. Through an anonymous discussion, individuals accepted the attitude that rights are inalienable, but still expressed the need for children to learn and accept their obligations as a prerequisite of realization of rights of others, and as one of the educational task of the family.

Regarding a straightforward question of How can the state family policy contribute to the quality of family functioning?, research participants provided opinions that can tentatively be classified as: general attitudes, measures to facilitate the fulfilment of certain family functions, pro-family and social measures. All statements were given in order to be assessed [Table 8].

Table8. Assessment of Family Policy Measures That Would Contribute to Better Quality of Family Functioning.

\begin{tabular}{|l|l|l|l|}
\hline \multicolumn{1}{|l|}{ SD } & $\mathbf{v}$ \\
\hline $\begin{array}{l}\text { It is the obligation of the state to provide quality institutional education for children } \\
\text { of early and preschool age * }\end{array}$ & 4.55 & .754 & .568 \\
\hline The state should provide preventive measures for families with a risk factor. ** & 4.33 & .736 & .542 \\
\hline Family policy measures should facilitate the organization of family life. * & 4.33 & .595 & .354 \\
\hline $\begin{array}{l}\text { Family policy measures should help young families the easily acquire the "first real } \\
\text { estate" (as a starting point for the creation of a family) }\end{array}$ & 4.27 & .761 & .580 \\
\hline $\begin{array}{l}\text { If we accept a family as a form of social capital, the state is obliged to provide } \\
\text { conditions in order to facilitate family life (childcare, financial incentives). * }\end{array}$ & 4.27 & .839 & .705 \\
\hline $\begin{array}{l}\text { Family law must ensure two-way regulations on parental obligations toward } \\
\text { children and vice versa. }\end{array}$ & 4.09 & .765 & .585 \\
\hline $\begin{array}{l}\text { In accordance with the Convention on the Rights of the Child, it is necessary to } \\
\text { clearly define the optimal interest of the child. }\end{array}$ & 3.82 & .983 & .966 \\
\hline The state should largely financially support families with more children. & 3.63 & 1.008 & 1.016 \\
\hline $\begin{array}{l}\text { The state should be able to introduce quality family time (through system } \\
\text { institutions, as a part of the educational process). }\end{array}$ & 3.61 & .827 & .684 \\
\hline $\begin{array}{l}\text { Ensure a longer parental leave since it has a positive effect on the quality of family } \\
\text { functioning }\end{array}$ & 3.24 & 1.032 & 1.064 \\
\hline $\begin{array}{l}\text { Maternity leave should be extended to the child's third year in oder to allow for } \\
\text { building of emotional, secure attachment between children and parents. }\end{array}$ & 3.13 & 1.212 & 1.468 \\
\hline Parents should be able to work half-time until the child starts school. & 3.06 & 1.223 & 1.496 \\
\hline
\end{tabular}

* absolute consensus ** relative consensus

Research participants gave the prime importance to the statement It is the obligation of the state to provide quality institutional education for children of early and preschool age. Legal guidelines guarantee for all children the right to some form of institutional care and education, while the responsibility for its implementation belongs to the local government units, in accordance with their capabilities, and not according to the needs of parents. Absolute consent was achieved for the following statements: Family policy measures should facilitate the organization of family life and if 
we accept a family as a form of social capital, the state is obliged to provide conditions in order to facilitate family life (childcare, financial incentives). It is possible to conclude that research participants agree that the state is obliged to take measures that can make life easier for families and indirectly contribute to the quality of family functioning, but they do not agree on the assessment of significance of certain family policy measures. Participants discussed how certain measures truly contribute to the welfare of children in the family, and when and how the state is obliged to interfere [Table 9].

Table9. Assessment of State's Obligations with the Aim of Optimal Protection of Children

\begin{tabular}{|l|l|l|l|}
\hline & M & SD & v \\
\hline The state is obliged to react if children in families are at risk & 4.67 & .64 & .41 \\
\hline Taking the children away from their parents is an extreme repressive measure & 4.45 & .79 & .63 \\
\hline $\begin{array}{l}\text { The state should recognize poor quality parents and provide conditions of extra- } \\
\text { familial education }\end{array}$ & 4.03 & .84 & .70 \\
\hline Longer parental leave is associated with higher quality of family functioning & 3.24 & 1.03 & 1.06 \\
\hline
\end{tabular}

Although the majority of research participants agree that the state is obliged to interfere if children in families are at risk, they disagree as to who assesses the vulnerability of children, i.e. what the mechanisms for monitoring the well-being of children in a family are. Certain participants in the study (lawyer, economist) state that the (excessive) state interference in family life represents an interference in the fundamental rights of the individual. They deem questionable the alleged solutions which employ the taking away of children from their families because they are of opinion that the state does not offer quality replacement solutions. Research participants also expressed conflicting views in relation to the generated statement on the link between parental leave and family functioning. Certain research participants (psychiatrist, educator-theologian) expressed the need for early parental care, especially from mothers. In contrast to that, other participants (economist) point out the difficult economic functioning of the family as a result of unemployment of one parent or a lack of compensation during maternity leave. Educators (over)emphasize the importance of institutional early and pre-school education in relation to the family upbringing which is not in accordance with recent longitudinal studies on the welfare of children followed by an early inclusion in nurseries and kindergartens. In the context of research, it is justified to also analyse the opinion of research participants about global trends in corporations that co-finance the stay of employees' children in the institutions of early and pre-school education [Table 10].

Table10. Assessment of Tendency of Corporative Care for Children of Early and Preschool Age.

\begin{tabular}{|l|l|l|l|}
\hline & M & SD & v \\
\hline $\begin{array}{l}\text { In order to keep highly educated employees, large companies will take over the } \\
\text { role of organized child care (especially for children of early and preschool age, } \\
\text { i.e. the companies will open a corporate kindergarten). }\end{array}$ & 4.18 & 1.211 & 1.466 \\
\hline $\begin{array}{l}\text { Organized childcare for children of early and preschool age provided by } \\
\text { companies (corporate kindergartens) will have a negative educational } \\
\text { consequence in the long run. }\end{array}$ & 2.64 & 1.245 & 1.551 \\
\hline
\end{tabular}

For both statements a partial consensus was achieved by research participants who assume the opening of corporate kindergartens to be a real possibility and in fact do not consider it as a problem. They value the employment of parents as a necessity which will in the long run, through the economic security, contribute to the welfare of children. Opposing views were expressed by individuals (psychiatrist, lawyer) who evaluate the well-being of children through as longer parental involvement as possible in early childcare, and believe that the institutional early and pre-school education cannot compensate nor replace family upbringing and growing up in a family environment.

\section{Conclusion}

Following the conducted empirical research, analyses and triangulations with recent studies on the quality of family functioning and well-being of children, it is reasonable to conclude that quality family functioning is indeed a predictor for the realization of children's right to grow up in a family. As indicators of the quality of family functioning, one can emphasize: the emotional connection and attachment between family members, cooperative relationships recognizable through mutual trust and ways of dealing with problem situations, flexibility of the structure of time spent together and of family roles, which is in agreement with recent world-wide studies. Research participants recognize and correlate, as significant indicators of the quality of family functioning, also the expressed 
attachment between parents and the harmony of parental behaviours, which indicates the significance of family structure. At the same time, the majority of worldly research indicates that the family structure is not a good independent predictor of the quality of the conditions of children in the family, although it is recognizable in the long term through a sort of transfer of parenthood.

Global processes, especially the economic crisis, reflect on the structure of the family and family functions, and indirectly affect the conditions of growing up of children in families. Adequate measures of family and social government policies can facilitate family functioning, but cannot guarantee the quality of family functioning, which is important for the quality of growing up and the long-term well-being of children. It is thus justified to interpret the right of children to grow up in a family as a request for a quality family life which depends largely on the parents, but also on the objective conditions of the family environment.

\section{REFERENCES}

[1] Widmer, D., Family Configurations: a Structural Approach to Family Diversity, England, Ashgate Publishing Limited (2010).

[2] Minuchin, S., Family Healing: Strategies for Hope and Understanding. Free Press (2008).

[3] Stangeland, J. D. and C. A. Walsh., Defining Permanency and Aboriginal Youth in Foster Care. First Peoples Child \& Family Review 8(2), Pp. 24-39, (2013).

[4] Brown, I. Putting a human face on child welfare: Voices from the prairies Regina. Child Welfare Consortium, 2007, ch. 9, pp. 189-202.

[5] Belsky, D. Etiological features of borderline personality related characteristics in a birth cohort of 12-year-old children. Development and Psychopathology 24(1), Pp. 251-265, (2012).

[6] Ljubetić, M. Biti kompetentan roditelj, Zagreb, Mali professor (2007).

[7] Štalekar, V. Dinamika obitelji i prvi teorijski koncepti. Medicina Fluminensis 46(3), Pp. 242246, (2010).

[8] Wagner Jakab, A. Obitelj-sustav dinamičnih odnosa $u$ interakciji. Hrvatska revija za rehabilitacijske istraživanja 66(2), Pp. 119-128, (2008).

[9] Olson, D. H. FACES IV and the circumplex model: Validation study. Journal of marital and family therapy 37(1), Pp. 64-80, (2011).

[10] Beavers, R. and Hampson, R. B. The Beavers Systems Model of Family Functioning. Journal of Family Therapy, 22(2), pp. 128-143, (2000). doi:10.1111/1467-6427.00143

[11] Olson, D. H. Circumplex Model of Marital and Family Systems. Journal of Family Therapy, 22(2), Pp. 144-167, (2000). doi:10.1111/1467-6427.00144

[12] Barnett, W. S., and C. R. Belfield. Early childhood development and social mobility. Future of Children 16(2), Pp. 73-94, (2006).

[13] D'Addato, A. Promoting prevention and early intervention, Eurochild's contribution to the peer review The Federal Foundation Mother and Child for pregnant women in emergency situations, Germany, 21-22, Pp. 1-9, (2010).

[14] Vandell, D. L. Do effects of early child care extend to age 15 years?: Results from the NICHD study of the early child care and youth development. Children Development 81(3), pp. 737-756, (2010).

[15] Juul, J., and H. Jensen. Od poslušnosti do odgovornosti. Zagreb, Profil, (2010).

[16] Regnerus, M. Parental same-sex relationships, family instability, and subsequent life outcomes for adult children: Answering critics of the new family structures study with additional analyses. Social science research 41(6), pp. 1367-1377, (2012).

[17] Maleš, D. Nove paradigme ranoga odgoja. Zagreb, Filozofski fakultet Sveučilišta u Zagrebu, Zavod za pedagogiju, (2011).

[18] Amato, P. R. Učinci rastave braka na odrasle i djecu: najnoviji nalazi. Društvena istraživanja 23(1), pp. 5-24, (2014).

[19] Biblarz, T. J. and Stacey, J. How Does the Gender of Parents Matter?. Journal of Marriage and Family, 72(1), Pp 3-22, (2010). doi:10.1111/j.1741-3737.2009.00678.x 
[20] Wise, S. Family structure, child outcomes and environmental mediators: An overview of the development in diverse families study. Melbourne, Australian Institute of Family Studies, (2003).

[21] Rosenfeld, M. J. Nontraditional families and childhood progress through school. Demography 47(3), Pp. 755-775, (2010).

[22] Belsky J. Social-Contextual Determinants of Parenting. Encyclopedia of Early Child Development, Montreal, Quebec: Centre of Excellence for Early Childhood Development, (2014).

[23] Cohen, L., L. Manion, and K. Morrison. Metode istraživanja u obrazovanju. Jastrebarsko, Naklada Slap, (2007).

[24] Van der Schaaf, M. F., and K. M. Stokking. Construct Validation of Content Standards for Teaching. Scandinavian Journal of Educational Research 55(3), Pp. 273-289, (2011).

\section{AUTHOR's BIOGRAPHY}

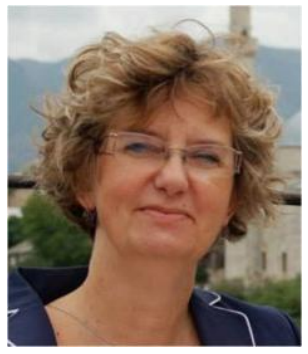

Ivana Viskovic, Ph.D. in Education Sciences. Assistant professor in University of Herzegovina at the Department of Education. Interest areas of research are family and preschool pedagogy and the methodology of scientific research. She has published several scientific papers, three editorial books, manual of methodology of preschool education. She is a member of the expert working group for the National Curriculum of early and preschool education in Croatia. 